\title{
Enculturation into Discourses by East Asian Students in a Graduate TESOL Program
}

Mari Haneda

Through multiple case studies, this article examines the learning experiences of three Korean students in a MATESOL program and how they made sense of the Discourses (Gee, 1996) that they encountered in their course work. The students experienced enculturation on three interrelated dimensions: disciplinary, linguistic, and cultural knowledge, the latter two initially posing the greatest difficulty. The Discourse(s) that they experienced appeared to be a mixture of professional and academic Discourses. However, this hybridity did not seem to be explicitly recognized either by the entering students or even by the contributing faculty, which resulted in feelings of uncertainty among the students.

Par le biais de multiples études de cas, cet article décrit les expériences d'apprentissage de trois étudiants coréens inscrits au programme de maîtrise TESOL (Teachers of English to Speakers of Other Languages) et explique comment ils ont compris les discours (Gee, 1996) auxquels ils ont été exposés pendant le cours. Les étudiants ont été enculturés sur trois plans interreliés: les connaissances disciplinaires, linguistiques et culturelles. Dans un premier temps, se sont les deux dernières composantes qui ont posé les plus grandes difficultés. Les discours auxquels ils ont été exposés semblaient être un mélange de discours professionnels et académiques. Toutefois, cet hybridisme ne semblant pas être explicitement reconnu ni par les nouveaux étudiants, ni par le personnel enseignant, les étudiants en ont retiré des sentiments d'incertitude.

\section{Introduction}

Research on academic enculturation has tended to be skewed toward undergraduate and doctoral education, leaving the process of enculturation at the master's level relatively unexplored (Casanave, 2002). Addressing this gap, in this article I examine the forms of enculturation that took place in a graduate TESOL program in North America that serves a substantial number of students from overseas. More specifically, I examine two issues: the process of three Korean ESL students' enculturation in their first year of MA studies in a Midwestern United States university, and how they made sense of the Discourses (Gee, 1996) into which they were being socialized.

In this article the term academic enculturation is used as it has been used in both higher education and writing research: it refers to a process of cultural 
learning in which graduate students learn to act as productive members of their disciplinary communities and locally of their graduate departments (Boyle \& Boice, 1998; Casanave \& Li, 2008; Delamont, Atkinson, \& Parry, 1997). By contrast, other similar terms such as acculturation and assimilation, used in such fields as anthropology, immigration studies, and second-language acquisition, refer to processes that newcomers undergo as they become integrated into a new cultural linguistic community in which they intend to settle (Alba \& Nee, 2005; Portes \& Rumbuat, 2006; Schumann, 1986).

\section{Theoretical Considerations}

\section{From Discourse Community to Academic Literacies}

The defining characteristics of a discourse community according to Swales (1990), include having common goals, genres, and associated lexis; mechanisms to communicate among members; and a sufficient number of members with knowledge about relevant content and discourse expertise. The premise that there is a relatively unified disciplinary discourse community into which students are enculturated by adopting known sets of genre practices is also shared by earlier research on disciplinary practices in higher education (Bartholomae, 1985; Berkenkotter, Huckin, \& Ackerman, 1988; Walvoord \& McCarthy, 1990). From this perspective, newcomers are expected to master ways of talking, writing, thinking, and using literacy that typify members of a disciplinary community and thus to reproduce them.

However, in recent years this portrayal of consensual, stable, rulegoverned discourse communities has been challenged theoretically and empirically in composition studies (Chiseri-Strater, 1991; Cooper, 1989; Prior, 1998), new literacy studies (Ivanic, 1998; Lea \& Street, 2000, 2006; Lillis, 2001), and second-language research (Belcher, 1994; Canagarajah, 2002; Leki, 2007; Riazi, 1997). These studies have brought to light the more complex and dynamic nature of disciplinary communities involving both epistemological issues and "social processes, including power relations among people, institutions, and social identities" (Lea \& Street, 2006, p. 369). Furthermore, it has been shown that academic enculturation is not simply about students' passive internalization of dominant discourses. Casanave (2002) showed that students can exercise their agency by selectively appropriating some rules of the community, by resisting or rejecting others, and by taking advantage of slippages in the system.

This contested nature of discourse communities is emphasized in the academic literacies model proposed by Lea and Street (2000), who contended that literacy practices as enacted in specific classrooms differ because of the varied epistemological orientations of instructors and how certain kinds of knowledge become privileged over others in particular classes. It is, therefore, not surprising that in practice, the resulting disjuncture may cause some 
confusion for students who need to move from one course to another, particularly in undergraduate education. To capture this ideological nature of literacy practices adequately, Lea and Street argued for the need for a pluralistic conception of academic literacies that views "the institutions in which academic practices take place as constituted in, and as sites of, discourse and power" (p. 35).

Highlighted in the academic literacies model are the ideological nature of literacy practices and the negotiation of identities that students must perform as they try to make sense of the conflicting practices that they may experience. These two issues have also become prominent in recent writing research. For example, Hirvela and Belcher (2001) described how international doctoral students in a US university-accomplished professionals in their home countries and in their native languages-struggled to create distinct voices in English by reconciling their prior professional identities (e.g., an established journalist in the home country), their status as relative novices in academia, and the disciplinary requirements of the programs they entered.

This connection between identity and academic enculturation is also at the core of Gee's (1996) notion of Discourse, which aligns well with the academic literacies model. Discourse with a capital $D$ refers to "ways of behaving, interacting, valuing, thinking, believing, speaking, and often reading and writing that are accepted as instantiations of particular roles (or 'types of people') by specific groups of people" (p. viii). In this framework, becoming members of academic discourse communities involves appropriating the oral and written genres of the relevant disciplines and taking up socially recognizable roles in these communities.

\section{Research on University-to-Work Transition and Academic Enculturation at the MA Level}

In this section I selectively review research on the transition from university to work settings and academic enculturation at the master's level, both of which are relevant to this study. Generally, research on the transition from university to work has shown that students' writing in academic contexts differs significantly from what is expected in their workplace (Casanave, 2002). For example, Freedman and Adam (1996) reported that MA students writing in the workplace in an internship program needed to devise their own ways of learning when on the job. In place of the explicit assignments and evaluation criteria with which they were familiar from coursework, the internship writing tasks that they faced were rather vaguely defined; their supervisors expected them to take more responsibility for their writing than did their professors. Similarly, noting the "contradictions between the activity systems of the workplace and the classroom" Dannels (2000, p. 27), in her study of fourth-year engineering students, suggested that academic programs that intend to help students become professionals should be more 
challenging, reflective, and authentically professional than the one she studied.

With respect to research on enculturation at the master's level, Morita (2004), in her study of Japanese female master's students in education in a Canadian university, revealed students' agency in carving out their learning paths. She reported that these students negotiated competence and membership in classroom communities in varied ways: they positioned themselves as knowledgeable, devised strategies to obtain assistance, resisted ascribed identities as students with limited English, or resorted to nonparticipation (Norton, 2001). Also conducted in a Canadian university, a study by Raymond and Parks (2002) showed that Chinese ESL students in an MBA program experienced wide-ranging micro-enactments of academic socialization across classes. In particular, the students' success in various courses appeared to depend partly on the differential availability of instructors' scaffolding, including the use of oral debate in groups and oral reviews.

There is also the question of the kinds of Discourse to which students are being apprenticed. Not only do diverse fields of study exist in academia, but also diverse Discourses exist in the same discipline, depending on the varied specializations in the discipline and o the stage that students have reached in their careers. In this respect, Russell (1997) noted that whereas undergraduate students in introductory or intermediate cell biology courses tended to take the role of knowledge receiver or act out the identity of doing school, graduate students tended to see themselves as prospective constructors of knowledge in their discipline. Thus the Discourses in which undergraduate and graduate students engage seem to differ greatly.

What might then be the nature of the Discourse(s) into which master'slevel second-language education students are socialized? Instructive in this respect are studies by Casanave (2002) and Freeman (1996). Casanave conducted a qualitative study of five female students' (both ESL and non-ESL) experiences in a research-oriented MATESOL program. Despite their varied learning trajectories, all were carefully apprenticed into the community of language-teaching professionals through intensive scaffolding from faculty (e.g., careful written feedback on students' writing, setting high standards for students' work, and role modeling). Unlike Morita's (2004) participants, whose priority was extending their oral participation, these students were centrally concerned with developing their competence as academic writers, considering fluency with various written genres as key to becoming legitimate members of the community of language-teaching professionals. In Casanave's study, therefore, the participants were socialized into the Discourse of language-teaching professionals who not only can perform professional oral and writing tasks, but also are well versed in current applied linguistics research and proficient in academic writing. 
Freeman's (1996) two-year qualitative study, which examined novice inservice second-language teachers enrolled in a master of arts teaching (MAT) degree, made a case for the importance of considering the change experienced by new teachers, not in terms of changes in their behavior or actions, but in terms of changing perspectives on their practice as a result of their participation in a teacher-education program. Freeman reported that the participants' conception of practice changed when they became able to articulate the problematic situations encountered in their teaching by reframing them in the light of the subject matter knowledge and the professional metalanguage that they were developing in their courses. In other words, by participating in the MAT program, they became agents able to diagnose their difficulties more precisely or to rename them in the professional Discourse of L2 teachers and also to restructure their conception of teaching, supported by faculty modeling of this Discourse.

In sum, much of the relevant recent literature adopts a view of academic discourse communities as fluid, dynamic, contested, and ideological. As described by the academic literacies model, the classroom enactments of academic literacy practices may vary considerably even in the same discipline, according to instructors' epistemological orientations, the kinds of knowledge that become privileged over others in particular classrooms, and institutional affordances and constraints. Academic enculturation, that is to say, becoming a member of particular discourse communities, involves appropriating the oral and written genres of the relevant disciplines, negotiating identities, and taking up socially recognizable roles in these communities: what Gee (1996) calls enculturation into Discourse(s). Further, of particular relevance for this study is a recent conceptualization of academic enculturation that considers students as active agents in their own enculturation. In other words, they are no longer seen as those who passively internalize dominant discourses, but as those who selectively appropriate some aspects of those discourses, resist others, and negotiate their identities.

\section{This Study}

\section{Research Questions}

Of central concern to this article is how three Korean ESL students in a graduate TESOL program, relative newcomers to the US, made sense of their academic experiences and negotiated the unfamiliar norms and values and the Discourses that they encountered. With the issues reviewed in the above sections in mind, the research questions asked in the current study with respect to the three Korean ESL students involved were as follows.

1. How did they negotiate between their prior experiences as students and teachers and what was expected of them in the graduate TESOL program that they attended? 
2. How did they make sense of the Discourse(s) that they encountered and were expected to appropriate in this particular program?

\section{Research Context}

This qualitative study was conducted in a large Midwestern public university in the US over two quarters from January to June 2006. As this university follows a quarter system, an academic year is divided into four quarters, each of which lasts 10 weeks; the relative shortness of each term tends to lead to information-packed courses. The participants were three Korean ESL students in their first year of a MATESOL program in the College of Education. This five-quarter program usually has a high enrollment of international students, particularly from East Asia, as well as a smaller number of US students; the cohort for the 2005-2006 academic year numbered 15, over half of whom were students from Asia. However, the average size of the TESOL classes they attended was 25-30 because TESOL endorsement studentspracticing teachers who are seeking an additional qualification in TESOLalso took many of the same courses. Consequently, the MA students from overseas, who were already practicing or prospective EFL teachers, typically comprised approximately one third of the total membership of the classes that they took, and the remainder were US-based teachers of ESL, foreign languages, and general education. In addition, in a number of courses they found themselves with undergraduate and graduate students from other program areas; unlike Casanave's (2002) participants who took courses in a single program, the participants were required to take non-TESOL courses as part of their education degree requirements.

\section{Participants in the Study}

I was interested in the enculturation process of East Asian students as a result of my observations over several years that they tend to be good at creating support networks and to be successful in overcoming the difficulties that they encounter in their academic studies. I had hoped to recruit a combination of Korean and Chinese students, who typically constitute a large proportion of the international student population at my research site. However, in the academic year 2005-2006 in which this study was conducted, most of the international students in the TESOL program were from Korea, and the three students who voluntarily participated in the study happened to be Korean.

Of these three participants, Jin and Mi-na, who were in their early 30s, were experienced public school EFL teachers in Korea, and Sang-hee was a novice teacher in her mid-20s who had taught English grammar in a private cram school (see Table 1 for the participants' profiles; all names are pseudonyms). All stated that through their study in the MA program, they wished to increase their competence as EFL teachers and to improve their overall 
Table 1

Participants' Profiles

\begin{tabular}{llll}
\hline & Sang-hee & Jin & Mi-na \\
\hline Country of origin & Korea & Korea & Korea \\
Mother tongue & Korean & Korean & Korean \\
Length of stay in US & 2 years & 5 months & 2.5 years \\
$\begin{array}{l}\text { Previous study in North } \\
\text { America }\end{array}$ & One semester of & 5-month English & Church-sponsored ESL \\
Undergraduate major & college-level intensive & training for EFL & classes \\
Teaching experience & ESL Economics & teachers in & \\
& & Vancouver & English Education \\
& Private cram school & English literature & EFL teacher at a public \\
& (1.5 years) in Korea, & and linguistics & middle school in Korea \\
& teaching English & EFL teacher at & (8 years) \\
& grammar & public middle & \\
& & schools in Korea & \\
& & (11 years) & \\
\hline
\end{tabular}

English proficiency. They had selected this particular MA program because of its practical orientation as opposed to an emphasis on theory and research.

\section{Data Collection and Analysis}

With the assistance of a graduate student, I collected multiple sources of data for this case study research. The participants kept journals throughout the winter and spring quarters of their first year of MA study; each week they wrote about experiences that were significant and/or salient to them in two or three of the classes they took. In addition, three sets of semistructured interviews were conducted: at the beginning, middle, and end of the study. The first interview was carried out to gather baseline information about the individual students and their first-quarter experiences (30-40 minutes per participant). The second was a focus group interview exploring their secondquarter experiences (1.5 hours). The third interview was conducted individually, focusing both on the students' third-quarter experiences and on those of their first year as a whole (over one hour per participant); this interview also addressed issues that recurred in their journals. Moreover, my research assistant and I observed each of their classes at least once and wrote detailed field notes after each observation. The syllabi of all the courses that the participants took were also collected. In addition, the participants' written artifacts were selectively collected, including writing samples of which they were proud and those with which they had had some problems. In order to establish trustworthiness, analyses were conducted iteratively through multiple reading and coding of the data and cross-referencing 
across varied types of data, drawing on qualitative analytic techniques such as categorizing and contexualizing strategies (Maxwell, 2005). In addition, a cross-case analysis was conducted; under each of the major data-generated categories, including modes of class participation, group work, and coping strategies, I systematically identified similarities and differences across the three cases (Eisenhardt, 1989) and created a profile for each participant.

\section{Case Studies \\ Sang-hee}

Sang-hee, the mother of a young child, was in her mid-20s. Despite her quiet demeanor, she packed a great deal of energy and enthusiasm in her petite figure. At the time of the study she had already been in the US for two years as the spouse of a doctoral student. Before her arrival in the US, Sang-hee's teaching experience had been limited to one and a half years of teaching English grammar at a private cram school. Thus she considered obtaining a MA degree from a reputable North American university as essential for gaining a position as an EFL teacher in the public school system on her return to Korea. In order to keep up with her coursework, throughout the first year Sang-hee maintained a strict regime of getting up around 3:00 a.m. in order to compensate for her slow reading and writing speed in English and to complete all the assignments by the due dates.

In her first quarter, Sang-hee appeared overwhelmed by her MA study. Because her undergraduate major had been economics, she faced the double challenge of learning a new discipline, TESOL, and doing so in her second language. Sang-hee found it taxing to study solely in English, at times finding the group work required in many of her courses particularly challenging. This feeling was exacerbated when she took two non-TESOL courses with an undergraduate and graduate designation. According to Sang-hee, because of the many graded, in-class group activities, some undergraduates did not have the patience to work with international students, who had difficulty in expressing their opinions.

Sang-hee also talked and wrote about how she came to develop confidence as a prospective teacher, identifying the assignment for the syllabus design course as critical in this respect (Journal, February 20, 2006; Interview, April 7, 2006). For her needs analysis paper, she chose her husband as her target learner and examined his linguistic needs through a tailor-made questionnaire, observation of his interaction in a variety of contexts, and interviews. She was proud that she could conduct a systematic needs analysis and design an appropriate syllabus drawing on the theories that she had learned. Similarly, in the spring quarter she engaged in practice-oriented tasks, one example of which was to design two test specifications using part of the grade 7 curriculum in Korea. With the successful completion of each of these 
practice-oriented assignments, she felt a surge of increased confidence (Journal, April 12, 2006).

By contrast, however, Sang-hee reacted to the assignments that required the use of academic genres either as intellectual exercises or as something puzzling. For example, referring to a critical review paper of two articles that she was required to write in one course, she said: "It's a research paper. Actually it's for PhD students or researchers, right? But it's not so irrelevant. I just think it's a unique and special experience [to write this kind of paper]" (Interview, June 10, 2006). Another example was an essay assignment in her descriptive grammar course in the English department. She remained puzzled by the low grade assigned and the professor's comments on it. The whole class consisting of 42 students was involved in conducting a usage survey, examining the correlation between people's botheration level in response to grammatical errors (the extent to which people find linguistic errors acceptable or unacceptable) and their occupation, gender, age, and generation. A brief description of the assignment was provided in the course syllabus: "Besides participating in the on-line usage survey and recruiting others to take the survey also, you'll be asked to write an essay of 3-4 pages summarizing the survey results and responding to them in the light of class readings and discussions." According to Sang-hee, the professor did not provide additional instructions about this assignment except to say that the students needed to analyze the data. Sang-hee's interpretation of the term analyze was to tally the collected data according to variables, make graphs of overall correlation patterns, and comment on them. In the written feedback, the instructor pointed out that Sang-hee had merely described the data without any analysis and that she should have qualitatively analyzed the relationship between the subdata (e.g., how people's gender and age interacted with their botheration level). In the class of 42, despite not understanding the assigned task, Sang-hee felt uncomfortable about asking the professor to clarify what was expected (Interview, June 10, 2006).

Nonetheless, she was able to take more initiative in asking questions when the social organization of the class (e.g., a small number of students, a relaxed atmosphere) allowed her to take such risks. For example, as one of the requirements in the field experience course, she observed ESL classes in a public elementary school (30 hours) and worked with an experienced ESL teacher. In one-on-one interactions she bombarded her mentor teacher with questions, to which the teacher took ample time to respond. With the assistance of this teacher, she gradually came to understand the multiple aspects involved in teaching and to tease out diverse aspects for analysis (Interview, June 10, 2006).

In sum, in her first year of MA study, Sang-hee seemed to move from the initial stage of being overwhelmed by the demands placed on her in the new learning environment to the next stage in which she gradually built her 
confidence as a prospective language-teaching professional through successful completion of practice-oriented assignments in her TESOL courses (professional genres). However, she considered assignments that required her to write in academic genres as not directly relevant to her, but rather aimed at doctoral students. As the year progressed, she was also gradually able to take the initiative in asking questions when the social organization of the class allowed her to take more risks. Of note is that she kept to a strict regimen of work in order to keep up with her study: strategically exercising her agency.

\section{Jin}

Jin was an experienced teacher from Korea, having taught English in middle schools for 11 years. In her mid-30s, she was quiet, calm, and soft-spoken. Her study abroad was fully supported by a Korean government fellowship. In the past she had won several awards to further her studies, including an advanced study of EFL teaching at a Korean university. She also participated in summer English immersion camps as a teacher, which she considered a great privilege. Nevertheless, she decided to obtain an MA degree in order to further advance her EFL teaching skills and to improve her overall English competence.

Jin also found the first quarter "tough" because she had difficulty adjusting to her new living and learning environments. In the fall quarter, having found some professors and classmates hard to understand, she digitally recorded class sessions and listened to them everywhere (e.g., at home, while walking, in the library) in order not to miss any important points. Like Sang-hee, Jin found group work demanding. Her unease with group work was heightened during the winter quarter in two of her classes. For example, in her TESOL methods course, one of the requirements was a group project, designing a thematic unit using an integrated skills approach. Two US-born students in her group typically dominated the conversation and decided on the theme for their project without seeking agreement from the others. Frustrated by not being heard, Jin developed a coping strategy: she learned to position herself as an expert in her group by preparing ahead of class. As a result, Jin was able to present a detailed lesson plan to the whole group, which caused her group members not only to recognize her presence but also to respect her expertise as a language teacher.

To prepare for the group discussion, at home I spent a few hours, because we were supposed to bring $1 \mathrm{draft}$ of each other's lesson plan. Until now I didn't contribute much to the group project, so I felt stressed out over the project. To make up for it I made my lesson plan of speaking activity very hard and brought it to the group discussion. To my surprise, nobody made their lesson plan except me, and they 
thought mine was quite good, so they would adopt my style, which compensated my hard work and my pride. (Journal, February 8, 2008)

This incident changed the group dynamics for the rest of the quarter, eventually leading to satisfactory collaboration. Through this experience Jin also came to realize the need to develop communication strategies, including how to take and hold the floor, in order to participate actively in the conversation.

Another class that she found challenging was her adolescent literature class because the teaching style was drastically different from what she was used to in Korea; the instructor frequently used in-class graded group activities in which students needed to express their interpretation of novels in many ways including posters, dramatization, and oral presentations. This requirement for creativity was new to Jin as she was used to the Korean norm: teachers transmitting knowledge to students: "I was trained to accept what the author said or the professor said as truth. There's no reason for me argue with that" (Interview, June 9, 2006). Given this, she initially found the need to express her own views on novels challenging. However, half way through the course, she started to recognize the merit of this new approach to teaching literature and expressed her desire to teach literature similarly in the future (Journal, February 10, 2006).

However, despite her growing appreciation of this course, Jin felt that the instructor assumed too much knowledge about US popular culture, which she did not share (e.g., reference to The Simpsons, Saturday Night Live, professional baseball teams). In addition, she felt that her own cultural resources were not tapped into.

[In each class session] the professor asks us to discuss the given novel, and it is sweating time for me, because I am the only one who can't add anything to the discussion and sometimes I don't understand what the other people are talking about, which makes me feel stupid and helpless. I think maybe other people take me like that, even though I know I'm not stupid and I just don't have the background of American literature as they have. Instead I have plenty of knowledge of Korean literature. (Journal, January 26, 2006)

Eventually, in order to survive this course, four Korean students asked the instructor's permission to form a Korean group for all group assignments. Jin's strategy in this case, as in other classes, was to focus on quality written work. Consequently, she felt that her major improvement was in her writing competence in English, not in oral language as she had hoped.

Jin tended to assess the value of each assignment in terms of how useful it was for her future teaching. Because she was aware that her teaching practices had become routinized, she welcomed the opportunity to learn sound theoretical constructs and principles on which she could base her practices. 
Although she thrived when completing assignments in which she could make a direct link to teaching, she was less certain about what she was expected to do when an assignment required her to write in a more identifiably academic genre. For example, in one course she had to write a critical review of two articles that took divergent positions on the teaching of grammar. Not knowing what was expected of a critical review paper and not being given additional explanations about it in class, Jin followed the rubric literally. The criteria for evaluation for the rubric (for a total of 50 points) included summaries of each article (10), a critique of the two authors' arguments with textual evidence (20), the students' position on the debate (5), the clarity of writing (5), writing conventions (5), and adherence to APA style (5). Then, when she received written feedback, she learned that she should have expressed her own opinions in critiquing the two articles. Although Jin provided the pros and cons of each position succinctly, she did not think it was necessary to elaborate extensively on her position in the light of the rubric; this experience left her with feelings of puzzlement in the first quarter (Interview, December 20, 2005).

However, as Jin gained more confidence, she started to position herself as an experienced EFL teacher and consequently became more critical of teaching practices that did not meet her expectations. Although she appreciated one professor's use of highly detailed rubrics in the fall quarter 2005 when she had the same professor as in the spring quarter 2006, she questioned the professor's stance, which did not allow for any negotiation about how to approach the various assignments. Jin put it this way: "If every paper comes with the very tight or in detail rubric [as in this class] it makes me, you know, feel suffocated ... in the Spring quarter I started to think by myself with my own idea based on the textbook or lecturing" (Interview, April 9, 2006). However, she found that originality and creativity were allowed no place in her papers because the highly detailed rubrics restricted the content and format of each paper to what the professor required. By this stage, having come to trust her ability to do research on various topics, form her opinions, and express them in English, she was frustrated by having to write about what the professor wanted instead of being able to express her own views.

To summarize, Jin also appeared to move from feeling overwhelmed by the new environment (first quarter) to attempting to understand and participate in some of the classroom practices with which she was unfamiliar (second quarter), including group work and adopting a constructivist approach to teaching adolescent literature. As her studies progressed, Jin gradually gained confidence in her ability as a graduate student; she did this by strategically devising ways to participate in group work, developing some understanding of these unfamiliar practices, and successfully completing practice-oriented assignments in her TESOL courses. Interestingly, Jin seemed to move even further, to a third state in which she positioned herself 
as an experienced ELT professional and started to evaluate her learning experiences critically (spring quarter). In particular, she was critical of assignments that did not allow her professional voice to be heard. Although she tended to appreciate practice-oriented assignments in which she could make a direct link to her teaching, she remained unsure about the use value of academic genres under which some of her assignments fell.

\section{Mi-na}

Mi-na was energetic, outgoing, and talkative. Like Sang-hee, before her MA study Mi-na had already been in the US for two years as the spouse of a doctoral student. Mi-na was an experienced middle-school English teacher in Korea and wished to benefit from the graduate program by studying cuttingedge theories and L2 teaching approaches. She also wished to improve her English proficiency, particularly in oral language, because of the increasing public pressure in Korea for teachers of English to have advanced oral English proficiency. Of the three case-study students, she was the most forthcoming in speaking in English, both in social and academic settings.

In the winter quarter she wrote about her modes of oral participation in various classes, observing that she made frequent contributions in her TESOL courses (Journal, February 4, 13, 23). Mi-na frequently used the strategy of relating the topic under discussion to her Korean teaching context and her own teaching experiences. However, this was not successful in the adolescent literature course. Like Sang-hee and Jin, she found the group discussions in this course problematic because of her undergraduate classmates' fast-paced, slang-filled speech and her lack of knowledge about US popular culture, which the instructor took for granted.

In the spring quarter when I visited her in her classes, I noticed that in two she was extremely vocal whereas in the other she remained silent in the whole-class discussions. In my observation of one session of the class in which Mi-na chose to be silent, discussion focused on the pros and cons of using centers (some teachers like their students to work in groups, rotating through a number of tasks referred as centers). The professor nominated six native English-speaking students to share their experiences. Then after approximately 20 minutes in which the topic seemed to have been thoroughly discussed, the professor asked whether "colleagues from abroad" had something to share about the topic. None of the international students volunteered. Later Mi-na told me at length about failed experimentations with centers in her own school. When I asked why she had not mentioned this in class, she explained that because she was positioned as an outsider, she had no desire to contribute (Field notes, April 16, 2006).

Mi-na gradually built her confidence both through oral participation and through her written work. She was pleased that most of the written assignments in her TESOL classes were directly related to teaching. However, she 
became aware that despite successful completion of assignments in TESOL courses, she did not have a firm grasp of academic written genres. This realization struck her when she was writing an abstract for her final paper in one of the courses.

I realized that I had no idea how to write the abstract. Even if I planned to write what the topic is and what literatures I will refer to for my paper, I did not know about the form and the contents that I should put in the abstract ... I think the abstract is one of the genres of academic writing. However, I have never written such kind of writing. Last Fall quarter, I took the ESL writing course. Through the course, I was aware that academic writing is very different from other writings, because it has its own organizations and rhetoric. (Journal, February 23, 2006)

Like Jin, Mi-na also came to position herself as an individual with valuable teaching experience. By the spring quarter, she started to critique some of the teaching practices that did not meet her expectations. Mi-na, like Jin, criticized the use of tightly specified rubrics in one course because she believed that she could manage to organize a coherent paper on her own. Furthermore, from several of her graduate courses she had become aware of the importance of creating challenging tasks that push graduate students to synthesize the knowledge gained from various classes and make connections between theory and practice. Having recognized how she appropriated important professional genres (e.g., designing a course syllabus) by engaging in meaningful tasks herself, she now concluded that knowledge did not have to be imparted only by teachers. Rather, one of the teacher's responsibilities was to create challenging tasks to guide students in constructing knowledge for themselves.

To summarize, Mi-na built her confidence as a graduate student by actively participating in discussions and completing assignments that required her to write in professional genres in her TESOL classes. By the spring quarter, like Jin, Mi-na started to position herself as an experienced ELT professional rather than simply as a graduate student. With this change in perspective, she came to resist certain classroom practices that she felt positioned her unfavorably and critiqued those teaching practices that did not allow her autonomy. She also reconceptualized the role of the teacher as that of a guide who facilitates students as they construct their own knowledge rather than that of a knowledge transmitter. Of the three case-study students, only Mi-na was aware of the importance of writing in academic genres in graduate studies, although she did not fully understand the requirements of the academic genres in which she was asked to write. 


\section{Discussion}

Negotiating the Experiences of the Program

Lacking competence with respect to the linguistic and cultural knowledge dimensions of academic enculturation (e.g., turn-taking rules, knowledge about popular culture), the Korean students initially experienced a considerable degree of disorientation. However, they developed various strategies in order to compensate. They were determined to understand what was being said in class, keep up with the required work, and participate in discussions and group work. Interestingly, they tended to characterize their difficulty with their courses primarily in linguistic terms. However, analyses of the collected data suggest otherwise: at least in the oral participation mode, their difficulty was related not only to their oral fluency in English, but also to their unfamiliarity with North American culture and with appropriate classroom behaviors, which were sociocultural norms that their instructors took for granted. Group work constituted one such unfamiliar participation mode for the Korean students. However, as their studies progressed, they became strategic in how they participated. Further, when all their efforts failed, rather than simply accepting normative practices, they chose to resist them, a striking example of which was the formation of a Korean group to bypass the problem of having to deal with their native English-speaking peers.

A similar change in perspective also occurred with respect to teaching. As a result of their experience of the social constructivist approach adopted in some of their courses, they began to modify their views of the teacher's role, changing from seeing it as a transmitter of knowledge to seeing is as facilitator of students' learning. This was a major shift in perspective from that which characterized their experiences of learning and teaching in Korea. This finding is congruent with those reported by Freeman (1996) in that like the novice L2 teachers that he studied, the three Korean students in this study were enabled to articulate their earlier and current conceptions of teaching and to explain how their views had shifted as a consequence not only of their newly gained knowledge of the relevant subject matter, but also of their mastery of the professional language of teaching.

Also highlighted in this study are the varied ways that the three students created their own learning paths. As their studies progressed, the more experienced teachers-Jin and Mi-na-positioned themselves as competent ELT professionals with valuable teaching experience rather than as novice graduate students. They reported that their awareness of this change in perspective affected their interaction with peers and also their approach to writing. From the vantage point of ELT professionals, they also came to criticize those teaching practices that did not allow their professional voices to be heard. This can be argued as a case of "coming back to voice" (Hirvela \& Belcher, 2001); these two students appeared to reclaim their identity as established language teachers. On the other hand, Sang-hee adopted the 
stance of a novice language teacher who was in the process of developing her professional identity.

In sum, it can be said that in their first year of the MA program the participants experienced three major developments: (a) in their appreciation of the value of group work; (b) in their understanding of the grounds for adopting a constructivist approach to teaching; and (c) in their increasing confidence in their own voice and their ability to evaluate their program experiences critically. It can be speculated that one central factor that made these changes possible was the students exercising agency to change their marginalized positions in the classroom communities in which they participated (Morita, 2004). Their agentive actions were manifested in varied ways: thoroughly preparing for group work, resisting normative classroom practices (regulating the extent to which they orally participated in discussions), creating a Korean work group, and critically appraising some of the class assignments.

\section{Making Sense of the Discourses Encountered}

The Discourses into which the students were being enculturated required them to appropriate the specific genres that they encountered in the program. Across their courses, the students experienced a range of written genres, some of which were typical of academic studies in various disciplines (part of academic Discourse), and others that were more professionally oriented (part of professional Discourse). Academic in this context is used in contrast to professional. This contrast is further discussed in the following section. They also encountered oral genres that occur across academic and professional Discourses. Most assignments in the TESOL courses involved professional genres (I use an expanded definition of genre, which includes curriculum and lesson plans as types of genre, Christie, 1997), the primary purpose of which appeared to be that of giving students opportunities to engage in simulated professional practices (e.g., conducting a needs analysis, developing language test specifications). In Shulman's (1987) terms, through these assigned genres the students increased their "pedagogical content knowledge" (p. 8): the intersection of subject-specific content knowledge, pedagogical knowledge, and knowledge of teaching contexts. Thus from the students' point of view, the program's general orientation toward professional ELT practices was well matched with their goal of developing advanced instructional competence as language-teaching specialists.

However, although the students were also expected to work with academic genres in some of their assignments, they continued to be mystified about the requirements of these genres with respect to purpose, content, structure, and style. Interestingly, the three students positioned themselves differently with respect to these academic genres. Sang-hee considered them as meant for doctoral students and therefore not really relevant for her, and 
Jin remained skeptical about their value in helping her to grow as a language-teaching professional. Only Mi-na was aware of the importance of academic genres in graduate studies; nonetheless, she did not fully understand the requirements of these academic genres and wished that her professors had explained them more thoroughly. This lack of explanation on the part of their instructors was fairly typical of the students' experiences of assignments that involved academic genres. Presumably, the instructors assumed that having completed an undergraduate degree, all students, both native English-speaking and international, would be familiar with these academic genres; by contrast, the professional genres required in the TESOL courses were treated as requiring a considerable amount of explicit instruction.

The students seemed to feel a sense of accomplishment in completing practice-oriented assignments because they were able to create professional artifacts building on learned theoretical knowledge. In other words, by using their academic knowledge, they agentively diagnosed practical problems and provided solutions to them (Abbott, 1988). However, with respect to the assignments that required academic Discourse, they were much less certain. In particular, although the rubrics devised for some of the assignments involving academic genres provided specific expectations for the required artifacts, they failed to project what kind of agents would produce these artifacts. Consider the critical review essay as an example: not clear to Jin about this genre was the kind of agent she should assume herself to be and the kind of voice she needed to create.

In addition, the students were unfamiliar with the oral genres in which they were expected to engage in both academic and professional Discourses. In some ways the students found these oral genres more challenging than the written genres, for although they could work at their own pace when writing, the oral genres required them to participate in real time at the pace set by the native English-speaking students. The problem for these three students was that the oral discourse genres that they encountered assumed the linguistic and cultural knowledge of US students, which was where they initially experienced the greatest difficulty. Nevertheless, despite their silence, which should have provided clear evidence to the contrary, these students were assumed to be already capable of, for example, recognizing the appropriate moment to contribute informed opinions about the assigned readings and taking the floor successfully. Over time, however, and largely through trial and error, the students did develop varying degrees of competence with oral classroom genres. Nevertheless, they displayed this competence strategically: in some cases they resorted to nonparticipation (Norton, 2001) in order to resist normative classroom practices that assigned them marginalized roles. From initially struggling to express themselves in speech, the students thus appeared to become more selective as to when and to what 
extent they would voice their opinions. As a result, their silence differed in its significance at various points in the program.

It seems clear that their overall orientation was toward professional Discourse. However, the assignments that they were set sometimes called for genres more associated with academic Discourse, and as described above, the students were uncertain both about the purposes of such assignments and about how to engage with them. This confusion was exacerbated by the absence of explicit guidance on the part of professors. At issue here is that the participants, namely, professors and students, did not share the same assumptions about academic Discourse, and this made it difficult for the students to know which Discourse they were expected to use on particular occasions.

\section{Implications for Programs that Include International MA Students}

Although the case studies presented in this article give only glimpses of the three students' experiences of enculturation, the findings suggest implications for theory and practice. First, it seems important to recognize that enculturation in graduate TESOL programs is multidimensional, involving both academic and professional Discourses. In concordance with the academic literacies model, the findings of this study also point to the range of micro-enactments of classroom literacy practices in closely related disciplines in which some types of knowledge are privileged over others. The academic literacies model focuses on undergraduates' experiences of taking classes across disciplines and their having to negotiate widely divergent practices. However, salient in this study is graduate L2 students' need to negotiate peer dynamics in group work and whole-class discussion and the challenge that the linguistic and cultural dimensions of enculturation can pose for those who have not grown up in the target culture (Morita, 2004; Leki, 2001). While acknowledging that the development of competence on the these two dimensions takes time, professors could make the process of enculturation less overwhelming by recognizing the need to explicate the norms of oral participation to international MA students and in lectures and class discussions provide explanations of items of cultural knowledge that may be unfamiliar to them.

In the case of the current study, it can be said that the program was primarily oriented toward professional Discourse. However, it is clear that students needed more explicit guidance with respect to particular written genres of academic Discourse: which genres are appropriate for which purposes, as well as the forms, conventions, style, and voice expected in particular genres. For international MA students to appropriate academic written genres, it would be beneficial to offer a variety of types of scaffolding, including peer discussion groups, textual models, multiple drafts, and peer editing. It appears that professors took for granted knowledge about oral and 
academic written genres and did not recognize the needs of international students. Thus it is of critical importance that these taken-for-granted assumptions be made explicit to international MA students.

Second, there was a perceived lack of fit between some of the universitybased written tasks and those actually used in professional settings. As noted above, Freedman and Adam (1996) found that the MA students in their study discovered that they needed to take more responsibility for their writing in the workplace than for their writing tasks in academia. In this study, however, the reverse occurred. The case-study students, particularly the two experienced teachers, found that some of the assignments in professional genres, which were rigidly structured, prevented them from drawing fully on their existing knowledge as language-teaching specialists. They perceived these assignments as unhelpful because of their tendency to encourage dependence on teacher-set criteria for the purpose of evaluation. These findings, which highlight students' desire to be agentive in their own learning, indicate that experienced professionals expect university tasks to mirror the kind of artifacts that they produced in their teaching contexts. Thus programs oriented toward professional Discourse need to survey current professional practices regularly in order to serve the needs of students who bring their previous work experiences to bear in their studies.

Finally, this study suggests the need to develop a more nuanced view of enculturation at the graduate level, one that takes account of both academic and professional trajectories. Master's and doctoral programs differ with respect to the stages reached in students' career trajectories. Particularly with respect to master's programs, it is necessary to distinguish between programs oriented toward academic careers and those that are professionally oriented. This distinction is of theoretical importance because it enables one to challenge the assumed homogeneity of academic enculturation. Which genres are emphasized in graduate programs ultimately depends on the purposes of enculturation: which Discourse(s) a program targets. Some such as TESOL are hybrids in this respect, but this is not always explicitly recognized either by entering students or even by contributing faculty. To reiterate the points made above, in order to make the process of enculturation transparent as well as enriching for entering international MA students, minimally needed in such programs are: (a) a coherent program vision of which specific Discourse(s) are to be taught, as was the case in Casanave's (2002) and Freeman's (1996) studies; (b) instructors who are committed to enacting the targeted Discourse(s) in their teaching while attending to the multiple dimensions of enculturation; and (c) the provision of explicit guidance for these students in terms of both the program goals and the implicit assumptions about the oral and written genres that are being used in their courses. 


\section{The Author}

Mari Haneda is an assistant professor of foreign/second language education as well as of language, education, and society in the School of Teaching and Learning at the Ohio State University. Her research interests include the language use and literacy practices of school-aged English-language learners and of L2 adult students, language and identity, and academic enculturation.

\section{References}

Abbott, A. (1988). The system of professions: An essay on the division of expert labor. Chicago, IL: University of Chicago Press.

Alba, R.D., \& Nee, V. (2005). Remaking the American mainstream: Assimilation and contemporary immigration. Cambridge, MA: Harvard University Press.

Barthlomae, D. (1985). Inventing the university. In M. Rose (Ed.), When a writer can't write (pp. 134-165). New York: Guilford.

Belcher, D. (1994). The apprenticeship approach to advanced academic literacy: Graduate students and their mentors. English for Specific Purposes, 13, 23-34.

Berkenkotter, C., Huckin, T.N., \& Ackerman, J. (1988). Conventions, conversations, and the writer: Case study of a student in a rhetoric Ph.D. program. Research in the Teaching of English, 22, 9-45.

Boyle, P., \& Boice, B. (1998). Best practice for enculturation: Collegiality, mentoring, and structure. In M.S. Anderson (Ed.), The experience of being in graduate school: An exploration. New Directions in Higher Education, No. 101 (pp. 87-94). San Francisco, CA: Jossey-Bass.

Canagarajah, A.S. (2002). Multilingual writers and the academic community: Toward a critical relationship. Journal of English for Academic Purposes, 1, 29-44.

Casanave, C.P. (2002). Writing games: Multicultural case studies of academic literacy practices in higher education. Mahwah, NJ: Erlbaum.

Casanave, C.P., \& Li, X. (Eds.). (2008). Learning the literacy practices of graduate school: Insiders' reflections on academic enculturation. Ann Arbor, MI: University of Michigan Press.

Chiseri-Strater, E. (1991). Academic literacies: The public and private discourse of university students. Portsmouth, NH: Boynton/Cook.

Christie, F. (1997). Curriculum macrogenres as forms of initiation into a culture. In F. Christie \& J.R. Martin (Eds.), Genre and institutions: Social processes in the workplace and school (pp. 134-160). London, New York: Continuum.

Cooper, M.M. (1989). Why are we talking about discourse communities? Or, foundationalism rears its ugly head once more. In M.M. Cooper \& M. Holtzman (Eds.), Writing as social action (pp. 202-220). Portsmouth, NH: Boyton/Cook.

Dannels, D.P. (2000). Learning to be professional: Technical classroom discourse, practice, and professional identity construction. Journal of Business and Technical Communication, 14, 5-37.

Delamont, S., \& Atkinson, P., \& Parry, O. (1997). Critical mass and doctoral research: Reflections on the Harris report. Studies in Higher Education, 22, 319-331.

Eisenhardt, K.M. (1989). Building theories from case study research. Academy of Management Review, 14, 532-550.

Freedman, A., \& Adam, C. (1996). Learning to write professionally: "Situated learning" and the transition from university to professional discourse. Journal of Business and Technical Communication, 10, 395-427.

Freeman, D. (1996). Renaming experience/reconstructing practice: Developing new understandings of teaching. In D. Freeman \& J.C. Richard (Eds.), Teacher learning in language teaching (pp. 221-241). Cambridge, UK: Cambridge University Press.

Gee, J.P. (1996). Social linguistics and literacies: Ideology in discourses (2nd ed.). London: Falmer. Hirvela, A., \& Belcher, D. (2001). Coming back to voice: The multiple voices and identities of mature multilingual writers. Journal of Second Language Writing, 10, 83-106. 
Ivanic, R. (1998). Writing and identity: The discoursal construction of identity in academic writing. Amsterdam: John Benjamins.

Lea, M,R., \& Street, B. (2000). Student writing and staff feedback in higher education: An academic literacies approach. In M.R. Lea \& B. Stierer (Eds.), Student writing in higher education: New contexts (pp. 32-46). Milton Keynes, UK: Society for Research into Higher Education and Open University Press.

Lea, M,R., \& Street, B. (2006). The "academic literacies" model: Theory and applications. Theory into Practice, 45, 368-377.

Leki, I. (2001). A narrow thinking system: Nonnative-English-speaking students in group projects across the curriculum. TESOL Quarterly, 35, 39-67.

Leki, I. (2007). Undergraduates in a second language: Challenges and complexities of academic literacy development. Mahwah, NJ: Erlbaum.

Lillis, T.M. (2001). Student writing: Access, regulation, desire. London: Routledge.

Maxwell, J.A. (2005). Qualitative research design: An interactive approach (2nd ed.). Thousand Oaks, CA: Sage.

Morita, N. (2004). Negotiating participation and identity in second language academic communities. TESOL Quarterly, 38, 572-603.

Norton, B. (2001). Non-participation, imagined communities, and the language classroom. In M. Breen (Ed.), Learner contributions to language learning: New directions in research (pp. 159-171). Harlow, UK: Pearson Education.

Portes, A., \& Rumbaut, R.G. (2006). Immigrant America: A portrait. Berkeley, CA: University of California Press.

Prior, P.A. (1998). Writing/disciplinarity: A sociohistoric account of literate activity in the academy. Mahwah, NJ: Erlbaum.

Raymond, P.M., \& Parks, S. (2002). Transitions: Orienting to reading and writing assignments in EAP and MBA contexts. Canadian Modern Language Review, 51, 152-180.

Riazi, A. (1997). Acquiring disciplinary literacy: A social-cognitive analysis of text production and learning among Iranian graduate students of education. Journal of Second Language Writing, 6, 105-137.

Russell, D.R. (1997). Rethinking genre in school and society: An activity theory analysis. Written Communication, 14, 504-554.

Schumann, J.H. (1986). Research on the acculturation model for second language acquisition. Journal of Multilingual and Multicultural Development, 7, 379-92.

Shulman, L.S. (1987). Knowledge and teaching: Foundations of the new reform. Harvard Educational Review, 57, 1-22.

Swales, J.M. (1990). Genre analysis: English in academic and research settings. New York: Cambridge University Press.

Walvoord, B., \& McCarthy, L. (1990). Thinking and writing in college: A naturalistic study of students in four disciplines. Urbana, IL: National Council of Teachers of English. 